\title{
Biology and distribution of butterfly fauna of Hazara University, Garden Campus, Mansehra, Pakistan
}

\author{
Farzana Perveen*, Fatima Fazal \\ Department of Zoology, Shaheed Benazir Bhutto University (SBBU), Main Campus, Sheringal, Pakistan; \\ *Corresponding Author: farzana_san@hotmail.com
}

Received 18 April 2013; revised 21 May 2013; accepted 30 May 2013

Copyright (c) 2013 Farzana Perveen, Fatima Fazal. This is an open access article distributed under the Creative Commons Attribution License, which permits unrestricted use, distribution, and reproduction in any medium, provided the original work is properly cited.

\section{ABSTRACT}

The butterflies are beautiful creature of nature with great economic importance as pollinator as well as bio-indicator of environments. The present survey was conducted to determine the biology and distribution of butterfly fauna of Hazara University, Garden Campus, Mansehra, Pakistan during March-June 2012. The study area was divided into 3 quadrates, i.e., residential area, administration area and main campus. A total of 170 specimens were collected, 10 species were identified belonging to 3 different families and falling in 8 genera. The species were identified. The painted lady, Cynthia cardui (Linnaeus); blue pansy, Junonia orithya Linnaeus; and plain tiger, Danaus chrysippus (Linnaeus) were belonging to family Nymphalidae. The lime butterfly, Papilio demoleus Linnaeus and common mormon, $P$. polytes Linnaeus were belonging to family Papilionidae. The dark clouded yellow, Colias croceus (Geoffroy); common grass yellow, Eumera hecab (Linnaeus); Murree green-veined white, Pieris ajaka Moore; greenveined white, $P$. napi (Linnaeus) and Bath white, Pontia daplidice (Linnaeus) were belonging to family Pieridae. The body sizes of $E$. hecabe and J. orithya were minimum, i.e., $1.4 \mathrm{~cm}(n=4-13)$, however, $D$. chrysippus was maximum, i.e., 2.5 $\mathrm{cm}(\mathrm{n}=1)$. The wingspan of $E$. hecabe was minimum, i.e., $3.7 \mathrm{~cm}(\mathrm{n}=4)$, however, $P$. polytes was maximum, i.e., $7.5 \mathrm{~cm}(\mathrm{n}=1)$. Proper preventive measures should be taken into consideration in order to minimize the natural habitat loss, as butterfly fauna is dependent upon proper environmental conditions.

Keywords: Biology; Butterfly; Distribution; Hazara University; Nymphalidae; Papilionidae; Pieridae

\section{INTRODUCTION}

Lepidoptera have significant economic importance. Butterflies are the most efficient pollinators of flowers in addition to moths and bees. They help in production of food crops, seeds and fruits, therefore, they are essential for the survival of man and animals [1]. Mouth parts of a butterfly are adapted for sucking. Proboscis is usually long and coiled. Compound eyes are comparatively large with a large number of facets. Larva is called caterpillar, usually eruciformes with a well-developed head. Caterpillar has well developed silk glands [2]. The antennae of butterflies are either slender or knobbed at the tip and in the family Hesperiidae (Skippers) are hooked at the tip. In some butterflies genera such as Taractrothera and common snout butterfly Libythea carinenta (Cramer) the knob is hollowed underneath [3].

Butterflies show remarkable mimicry in different forms. Batesian mimicry is between palatable and nonpalatable butterfly species, however, Mullerian mimicry, several equally unpleasantly tasting species share a color pattern and all species are mutually benefited, not only the mimic [4]. The constituents of wing arrangement and morphology that contribute to an impression of a head, though, differ prominently amongst lycaenid species [5].

A butterfly is a primarily day-flying insect belonging to order Lepidoptera, which also comprises moths in addition to butterflies [6]. Butterflies are the most plentiful group of insects on the earth, which are accustomed among the public and science due to their striking colors and elegant flight. These are found in every part of the world wherever the flowering plants are found residing even very high altitude except some regions such as Antarctic, Arctic, mountains roofed with everlasting snow and glaciers [7].

Butterflies are frequently used as bioindicators of ecosystem health and as surrogates for whole biodiversity [8]. Several characters of the butterflies make them good candidates for indicator species. They have a widespread 
distribution, are comparatively easy to sample and recognize, and both as individuals and as species, they show significant numbers in different ecosystems. They are also strongly influenced by local weather and highly sensitive to environmental changes besides being charismatic insects that could fascinate the public attention. Butterflies are extremely sensitive to changes in vegetation composition and structure, and different types of vegetation show different butterfly species composition [9]. Increased urban features, including roads, buildings, and mowed lawns, correspond with decreases in butterfly species richness, diversity and abundance. As might be predicted, butterfly species that specialize on particular plant species for ovipositing and disturbance sensitive species are more affected by urbanization than are generalist species [10].

Hazara University is situated in the North-East region of Pakistan. Throughout history the region has remained a melting pot of civilizations including Buddhist, Indian, Chinese, Islamic civilization and cultures. The university presently has 23 academic sections and comprises about 5000 on campus students. More than 69,000 students are registered in educational institutions affiliated with Hazara University, which is spread throughout the Hazara region of Pakistan [11]. It is situated in such area, which has blessed with the rich and symphonic combination of tall and splendid fine trees, plains, high mountains, lovely valleys and lakes which make it bliss of peace. Tree species are well exemplified by the deciduous and evergreen types. In avian fauna, several species are including Himalayan Monal, Lophophorus impejanus Latham and koklass pheasant, Pucrasia macrolopha Lesson are confined to hilly areas, whereas black partridge, Melanoperdix niger Vigors and grey partridges, Perdix perdix Linnaeus are also common. The birds of prey also inhabit this area. It has inclusive mammalian fauna comprising Rhesus monkeys, Macaca mulatta Zimmermann. Among the carnivores Cheetah, Acinonyx jubatus Schreber became extinct while the Snow leopard, Uncia uncia Schreber is endangered species (Figure 1) [12]. The objectives of the present research are to determine biology and distribution of butterfly fauna of Hazara University, Garden Campus, Mansehra, Pakistan.

\section{MATERIALS AND METHODS}

\subsection{Hazara University}

Mansehra district covers about $4579 \mathrm{~km}^{2}$ areas. It lies from $34^{\circ} 14^{\prime}$ to $35^{\circ} 11^{\prime}$ north latitudes and $72^{\circ} 49^{\prime}$ to $74^{\circ} 08^{\prime}$ east longitudes in Hazara Division, Pakistan [14]. Hazara

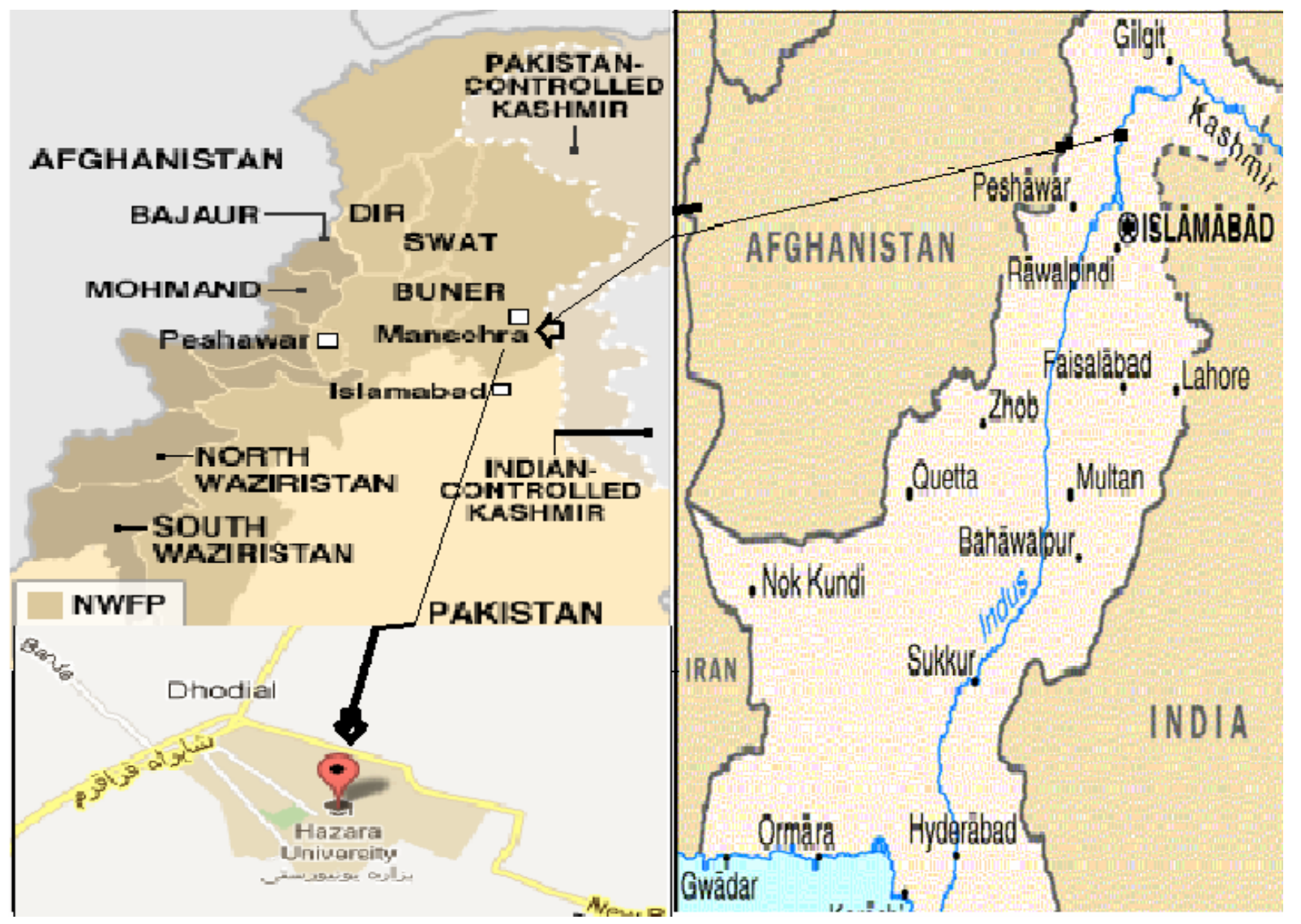

Figure 1. Map of Mansehra, Pakistan [13] where the survey area, Hazara University is located. 
University is situated $14 \mathrm{~km}$ to the north of Mansehra town on the right rim of Karakuram Highway. In 1997, Khyber Pakhtunkhwa (KP) Provincial Assembly passed Hazara University Act. In 2001, the then Governor, KP took the dauntless step of establishing Hazara University in the Dhodial [15]. For the present research, it was divided into 3 quadrants: residential area: A; administration area: B; main campus: C.

\subsection{Methods}

The study was conducted to know biology and distribution of butterflies of Hazara University Garden Campus, Mansehra, Pakistan. Each quadrant was visited daily twice or thrice in a day during March-June 2012 for collection of butterflies by sweep-net. Then they were killed, stretched to measure their wingspan. They were pinned and identified by already preserved specimen, internet, literature available $[16,17]$, keys $[17,18]$ and entomologists on the bases of their characteristics. All specimens were tagged and placed one by one on a white paper for photography with digital camera, Kodak (8.2 megapixels), Tokyo, Japan. Then they were arranged in the wooden box with the phenolphthalein balls. The literature about these species of butterflies was also collected.

\section{RESULTS}

The present study was conducted to determine the biology of the butterflies of Hazara University, Mansehra, Pakistan with their status and distribution. The university was divided in 3 quadrate of study sites, i.e., residential area: administration area: B; main campus: C. The specimens 92 were collected from residential area, 20 from administration area and 58 from main campus ( $\mathrm{n}=$ 170). Identification of these butterflies showed that 10 different species from 8 genera belonging to 3 different families were present in the area. Detailed biology of each species is provided below.

\subsection{Painted Lady, Cynthia cardui (Linnaeus 1758)}

Body length is $1.6 \pm 0.424 \mathrm{~cm}$ and wingspan is $5.65 \pm$ $0.636 \mathrm{~cm}$. It is pinkish red with black markings. Somewhat wavy hind wing is present. Apical half of the forewing is dusky black having white spots on it. Black markings are present on distal and median golden area. Hind wing has dense brown coloration with black spots on orange distal area and termini. Under hind wing is marked with bands, lines and spots. Four dark centered ocelli are also present under hind wing around discocellular region (Figure 2(a)). Sexes are alike and freshly emerged specimens have pinkish orange color which later on changes to dull tawny.

\subsubsection{Status}

It is uncommon in Sindh. It is present in northern hill areas, Baluchistan and Himalayas. In Northern areas, it can be seen from April-November.

\subsubsection{Distribution}

Khan et al. [19] recorded from district Bagh, Azad Kashmir, Pakistan. Ahson and Iqbal [21] from Lahore and Khan et al. [7,22] reported from Muzaffrabad. Abbas et al. [18] recorded from Skardu and Khan et al. [23] from Mirpur and Kotli. Naz et al. [24] reported from Buner and Iqbal [20] from district Rawalpindi and Islamabad. Shields [25] discussed the migration of $C$. caurdi.

\subsection{Blue Pansy, Junonia orithya (Linnaeus 1758)}

Wingspan is $3.85 \pm 0.50 \mathrm{~cm}$ and body length $1.4 \pm$ $0.108 \mathrm{~cm}$. In male, more than half of the forewing from base is velvety black to some extent, apical half dull fuliginous. Basal half of underside fore wing consists of 3 black-edged, broad, orange transverse bands. Two red brown black ringed ocelli are present on upper hind wing and wing is iridescent blue. In females, dull blue areas are present and ocelli are conspicuous. Across the cell, narrow black paired lines are present on under forewing. Under hindwing is of pale greyish buffy color. Brown bands are almost obsolete (Figure 2(b)).

\subsubsection{Status}

It is widespread in Indus Plain and Lower Baluchistan. In Sindh, it can be seen throughout the year.

\subsubsection{Distribution}

Khan et al. [19] reported from district Bagh, Pakistan and Pandharipande [26] from Central India. Previously, $J$. orithya was reported by Khan et al. [22] from Muzaffrabad, Azad Kashmir. Perveen and Ahmad [27,28] reported from Kohat and Khan et al. [23] from district Mirpur and Bhimber. It was also reported by Naz et al. [24]. Sharma and Joshi [29] recorded from Punjab Shivalik, India.

\subsection{Plain Tiger, Danaus chrysippus (Linnaeus 1758)}

Wingspan is $7 \mathrm{~cm}$ and body length $2.5 \mathrm{~cm}$ with color is tawny. The upper side is brighter and richer than the underside. Upper margin of fore wing is black with white spots. Hindwing consists of 3 black spots in male and 2 in female. The hindwing has a thin border of black encircling a series of hemispherical white spots. Male $D$. chrysippus is smaller than the female, but have more bright coloration (Figure 2(c)). 


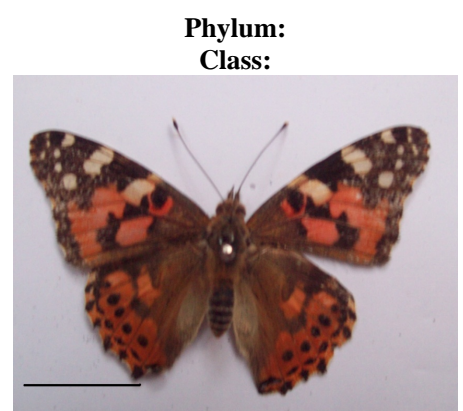

Family:

Nymphalidae Subfamily:

(a) Painted lady, Cynthia cardui (Linnaeus 1758)

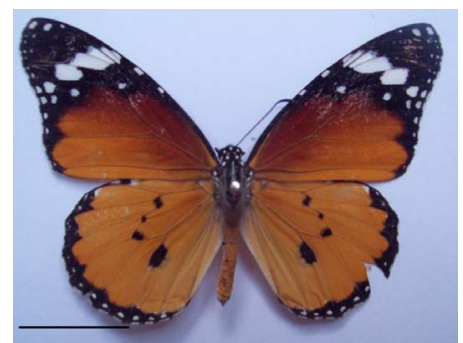

Family: Nymphalidae Subfamily: Danainae (c) Plain tiger, Danaus chrysippus (Linnaeus 1758)

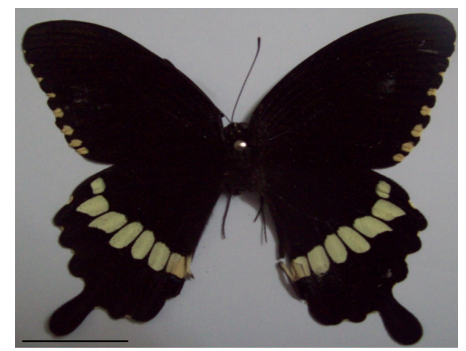

Family: Papilionidae Subfamily: Papilioninae e. Common mormon, Papilio polytes Linnaeus 1758

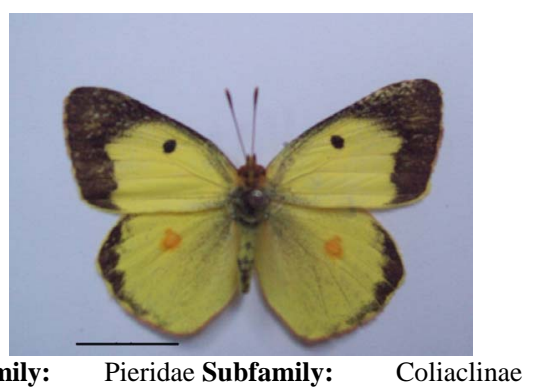

(g) Common grass yellow, Eumera hecab (Linnaeus 1758)

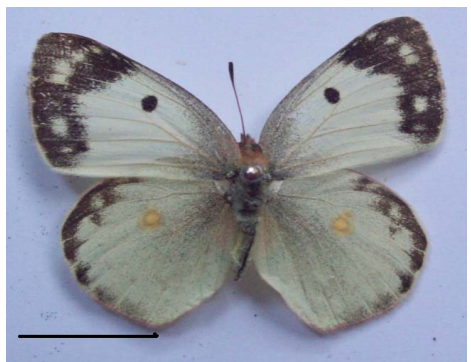

Family: Pieridae Subfamily: Pierinae

(i) Green-veined white, P. napi (Linnaeus 1758)

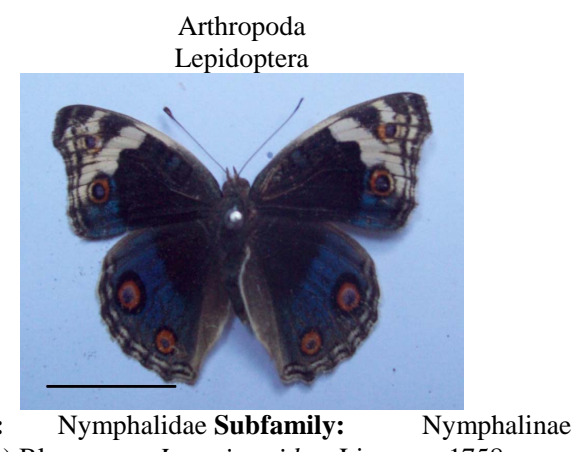

(b) Blue pansy, Junonia orithya Linnaeus 1758

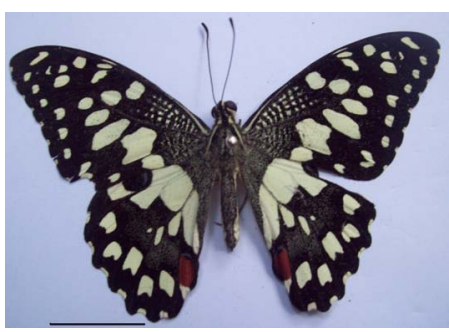

Family: Papilionidae Subfamily: Papilioninae d. Lime butterfly, Papilio demoleus Linnaeus 1758

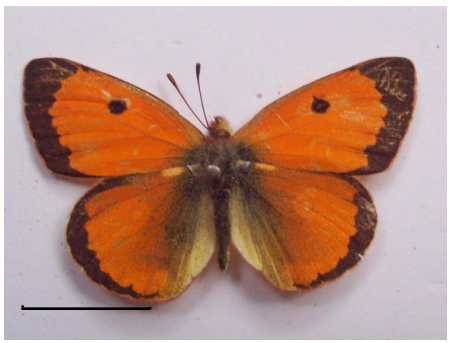

Family: Pieridae Subfamily: Coliaclinae (f) Dark clouded yellow, Colias croceus (Geoffroy 1785)

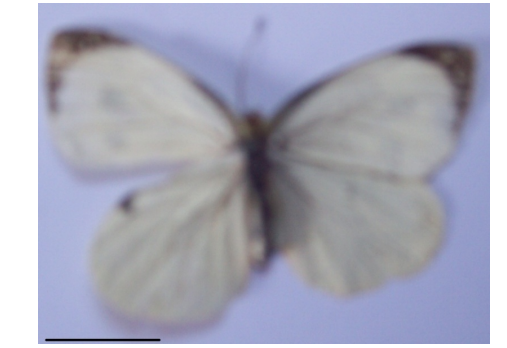

Family: Pieridae Subfamily: Pierinae

(h) Murree green-veined white, Pieris ajaka Moore 1865

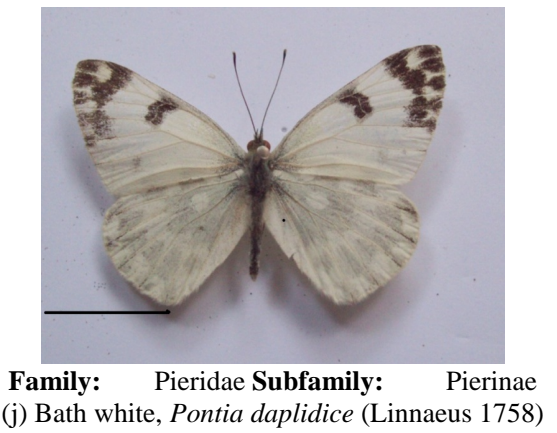

Figure 2. Classification of butterflies fauna collected during March-June 2012 from Hazara University, Pakistan. 


\subsubsection{Status}

The range of $D$. chrysippus extends from Africa and southern Europe, eastwards through India, Sri Lanka, and Myanmar to China and Sulawesi. It is a very common species.

\subsubsection{Distribution}

Ramesh et al. [30] reported from South India, Fermon et al. [31] from Republic of Benin, Khan et al. [19] from district Bagh, Pakistan and Pandharipande [26] from Central India. Khan et al. [7] reported D. chrysippus from Muzaffrabad, Azad Kashmir. Iqbal [20] reported from district Rawalpindi and Islamabad and Naz et al. [24] from Lahore. Tayyab et al. [32] reported from Bahawalpur, Khan et al. [23] from Kotli, Mirpur and Bhimber and Ahson and Iqbal [21] from Lahore. Sharma and Joshi [29] reported from Punjab Shivalik, India. Akhtar and Butt [33] studied the seasonal variation of $D$. chrysippus from Lahore.

\subsection{Lime Butterfly, Papilio demoleus (Linnaeus 1758)}

Lime butterfly can live in a broad variety of climatic conditions due to its wide range ecological tolerance ability. Wingspan is $7.1 \pm 0.782 \mathrm{~cm}$ and body length 2.15 $\pm 0.212 \mathrm{~cm}$. Body is dorsally black in color with large number of yellow strips. Apex of forewing has yellow spots present in a distal band. Hind wing is without any tail. Red spot is present at anal margin of hind wings. Blue black spot is also present along with red spot. Ventral body has paler yellow color, with the black areas dusted with yellow (Figure 2(d)). Upper side of butterfly is pale creamy, when it is freshly emerged. Later on, it changes to deeper yellow with sexes are similar.

\subsubsection{Status}

It is the commonest butterfly rarely occurring in lower valleys of Swat and Chitral. It can be frequently seen from August-October.

\subsubsection{Distribution}

Previously, it was reported by Khan et al. [19] from district Bagh, Pakistan, Pandharipande [24] from Central India and $\mathrm{Vu}$ and $\mathrm{Vu}$ [34] from Vietnam. It was reported by Tayyab et al. [32] from Agro-Forest area of Bahawalpur. Perveen and Ahmad [27,28] reported it from Kohat. Khan et al. [35] and Rafi et al. [36] reported from Islamabad and Rawalpindi. It was also reported by Ahson and Iqbal [21] from Lahore and Iqbal [20] from District Rawalpindi and Islamabad. Naz et al. [24] reported same species from district Buner, KP. Khan et al. [23] reported from district Mirpur and Bhimber, Azad Kashmir. Homoziak and Homoziak [37] recorded P. demoleus for the first time from USA.

\subsection{Common Mormon, Papilio polytes (Linnaeus 1758)}

Wing span is $7.5 \mathrm{~cm}$ and body length $2.3 \mathrm{~cm}$. Body of common Mormon is mainly black in color and has conspicuous tail on hind wing. It has a swift, rather spasmodic flight. Hind wing comprises a series of pale yellow spots. In male band of white spots or often creamy yellow spots is present on hind wing extending up to vein 7 . Fore wing contains white spots confined to the marginal area, which keeps on narrowing towards apex (Figure 2(e)). Females have developed many forms which have clear distinction from males.

\subsubsection{Status}

After monsoon and during monsoon, it is common in all provinces except Baluchistan. It occurs in almost all the plain up to Islamabad.

\subsubsection{Distribution}

Previously, it was reported by Khan et al. [19] from district Bagh, Pakistan, Vu and Vu [34] from Vietnam and Pandharipande [26] from Central India. It was reported by Tayyab et al. [32] from Agro-Forest area of Bahawalpur. Perveen and Ahmad [27,28] reported it from Kohat. Khan et al. [35] and Rafi et al. [36] reported from Islamabad and Rawalpindi. Previously, it was reported by Ahson and Iqbal [21] from Lahore and Iqbal [20] from district Rawalpindi and Islamabad. Naz et al. [24] reported same species from Chamla and Daggar area of district Buner, KP. Khan et al. [23] reported from district Mirpur and Bhimber, Azad Kashmir.

\subsection{Dark Clouded Yellow, Colias croceus (Geoffroy 1758)}

Wing span is $4.64 \pm 0.054 \mathrm{~cm}$ and body length $1.68 \pm$ $0.083 \mathrm{~cm}$. Upper surface of the male wings is orange colored without any spots. Outer border of upper surface is broad and black. Fore wing contains large black spots. Sometimes forewing veins are yellow outlined within the black margins. Hind wing consists of bright orange disco-cellular spot and is basally dusted with blackish orange. Black border with a series of small orange yellow spots of uneven sizes are present in females (Figure 2(f)).

\subsubsection{Status}

In Asia, its range extends into central Siberia in the north and barely into India, in the south. It is not found in Central Asia.

\subsubsection{Distribution}

It was formerly recorded from Knyszyn forest of Bialystok by Klimczuk [38]. Tayyab et al. [32] reported $C$. 
croceus from Bahawalpur and Perveen and Ahmad [27, 28] from Kohat.

\subsection{Common Grass Yellow, Eurema hecabe (Linnaeus 1758)}

Wingspan is $3.7 \pm 0.787 \mathrm{~cm}$ and body length $1.4 \pm$ $0.216 \mathrm{~cm}$. Body is lemon yellow both on upper and lower surface. Terminal and apical borders are blackish brown. Slightly pale yellow color underside comprises red brown markings which is only present on part of apex region. Under side cell base embraces 2 small spots. Large kidney shaped ring spot is also present in the disco-cellular region. Under hind wing includes discocellular red ringed blotch along with post-distal region curved lines (Figure 2(g)). Sexes are similar.

\subsubsection{Status}

It favors damper areas of Punjab and Sindh and also found in Baluchistan and cultivated parts of KP.

\subsubsection{Distribution}

$\mathrm{Vu}$ and $\mathrm{Vu}$ [34] reported from Vietnam and Khan et al. [19] from district Bagh, Pakistan. It was reported by Perveen and Ahmad from Kohat, Ahson and Iqbal [21] from Lahore. Khan et al. [23] from district, Mirpur and Bhimber and Naz et al. [24] reported from Buner. Iqbal [20] reported it from district Rawalpindi and Islamabad and Sharma and Joshi [29] from India.

\subsection{Murree Green-Veined White, Pieris ajaka (Moore 1865)}

Wingspan is $5.85 \pm 0.919 \mathrm{~cm}$ and body length $1.85 \pm$ $0.07 \mathrm{~cm}$. Male forewing have no trace of black spots in between vein 3 and 4 whereas females have prominent black spotting between vein 3 and 4 and between 1a and 1b. Pale yellow color is present at underside on both upper and hind wings. Grey dusting is present on margins of underside. Generally, males have less dark scaling and are paler on underside (Figure 2(h)).

\subsubsection{Status}

It occurs in northern valleys of Kashmir and Gurias and also found in Murree Hills but less common than $P$. napi.

\subsubsection{Distribution}

Shah et al. [39] and Perveen and Ahmad [27,28] recorded it from Kohat, Pakistan. Khan et al. [23] reported same species from Mirpur and Bhimber, Pakistan.

\subsection{Green-Veined White, Pieris napi (Linnaeus 1758)}

Wing span is $5.11 \pm 1.28 \mathrm{~cm}$ and body length $1.7 \pm$ $0.272 \mathrm{~cm}$. Tip of the forewing is black with black spots.
Hindwings have veins conspicuously black on the underside and it is dusted with pale-greenish yellow. In females fore wing heavy markings are present in black areas. The female has 2 spots on each forewing, the male have only one (Figure 2(i)). Sexes differ from each other like all white butterflies.

\subsubsection{Status}

It is present all over Swat and Lower Kaghan Valley. It is commonly found in Murree Hills. It prefers damper areas.

\subsubsection{Distribution}

Pandharipande [26] recorded it from Central India and Tayyab et al. [32] from Bahawalpur. Shah et al. [39] and Perveen and Ahmad [27,28] recorded it from Kohat, Pakistan.

\subsection{Bath White, Pontia daplidice (Linnaeus 1758)}

Wing span is $3.8 \pm 0.442 \mathrm{~cm}$ and body length $1.39 \pm$ $0.149 \mathrm{~cm}$. Dorsal surface is white in color. Apex of the forewing is dusted with black. Ventrally fore wing is white, dusted with green. Hind wing is green with white inner margin. Rounded white cell spot is present on underside of hind wings. Sexes can be differentiated by markings on the forewing. The male is distinguished from the female by the markings on the upper side of the forewing. The apex of the forewing is black with white spots and lines. There is a black spot at the end of the cell. In female, there is a surplus distal spot in 1b. Obscure row of terminal and marginal spots on the upper hindwing is also present in females (Figure 2(j)).

\subsubsection{Status}

In South Asia, the Bath white ranges from Baluchistan, Chitral, Peshawar, Kashmir and along the Himalayas right across the Central Himalayas up to Darjeeling. The butterfly seems to be extending its range westwards along the Himalayas.

\subsubsection{Distribution}

Khan et al. [19] recorded from district Bagh, Azad Kashmir, Pakistan. Same species was reported by Shah et al. [39] from Kohat and Naz et al. [24] from district Buner, Pakistan. Khan et al. [35] reported from Muzaffrabad, Azad Kashmir and Iqbal [20] from districts Rawalpindi and Islamabad. Khan et al. [23] reported same species from district Kotli, Bhimber and Mirpur, Azad Kashmir, Pakistan.

\section{DISCUSSION}

The present study is among the $1^{\text {st }}$ documented report for the butterfly fauna survey in Hazara University as 
well as Hazara division. A total of 170 specimens were collected and preserved from three different study sites of Hazara University. Identification revealed that 10 different species in 8 genera belonging to 3 families were present in area. These species are $P$. demoleus, P. polytes, P. daplidice, P. napi, P. ajaka, D. chrysippus, C. carudi, J. orithya, E. hecabe and C. croceus.

Shah et al. [39] made a survey of Kohat and collected 10 species belonging to only family Pieridae from seven different localities over a period of 7 months during 1999. In the present survey species belonging to different families were reported. $E$. hecabe and $P$. daplidice were recorded from both the surveys whereas P. ajaka. P. napi and $C$. croceus were only recorded from the present research. It may be due to the difference in climatic conditions of both the areas.

Perveen and Ahmad [27,28] evaluate the butterfly fauna of Kohat, Pakistan during September-December 2008. Twenty-one species were recognized belonging to 3 different families. Pieridae covered 57\%, Nymphalidae $33 \%$ and Papilionidae $10 \%$, of total numbers of collected butterflies of Kohat. Pieridae is reported as dominant family during survey. Similarly these three families were also reported in the present survey from Hazara University. Family Pieridae constitute large number of individuals followed by Nymphalidae and Papilionidae as reported in Kohat fauna.

Martinez et al. [40] reported biodiversity and biogeography of butterfly's fauna in Mexico. About 1800 species of butterflies were documented, constituting about $10 \%$ of the butterfly fauna of the world. The 21 sites were acknowledged in Mexico for the abundance of butterfly fauna and comparisons were made between these sites. Perveen et al. [41] reported the characterization and Perveen [42] described the distribution of butterflies of 5 sites of Kohat, Khyber Pakhtunkhwa, Pakistan. About 21 species of butterflies were documented. The collected species covered families Namphalidae, Papilionidae and Pieridae yielded 33\%, 10\%, and 57\% butterfly diversity of the area, respectively. In contrast, only 10 species were recorded from the present survey but difference was due differences in area covered in 3 studies. Comparison cannot be possible, however, almost same ecological conditions were found in the study areas.

Khan et al. [23] reported 16 species from Kotli, 20 from Mirpur and 19 from Bhimber, which showed great resemblance with species collected from Hazara University. The present research matched with butterfly faunal study of Skardu region by Khan et al. [7,22] as it revealed 16 species belonging to 5 families. Ahson and Iqbal [21] surveyed butterfly fauna of Lahore from a number of localities. In another study, 21 species were identified belonging to 3 different families from Kohat, Pakistan during September-December 2008. The re- ported families Namphalidae covered 33\%, Papilionidae $10 \%$, and Pieridae $57 \%$ biodiversity of butterflies of Kohat $[27,28,41,42]$. The butterfly species from fore mentioned studies, i.e., P. demoleus, P. polytes, D. chrysippus and $E$. hecabe were recorded showed resemblance with 10 species of butterflies from Hazara University.

Ambrose and Raj [43] evaluated Kalakad-Mundanthurai Tiger reserve Southern India butterfly fauna. Survey of about 7 months was done from September 2002March 2003. Study revealed 24 species of butterflies. Reported species of India belongs to 9 families but only 4 families were studied in detail. From the present research, only 10 species of 8 genera belonging to 3 families were recorded in restricted small area of Hazara University.

Hiller [44] studied the male genital structures of 3 species of butterflies from Rio Grande do Sul, Brazil. Same area was resided by 3 species at the same time of the year and their external morphology does not vary greatly, therefore, genital structures were taken into consideration for their identification. In the present research, species identified by distinguishable external morphology, therefore, genital structures were not studied.

Borang et al. [45] yielded 134 species of butterflies from area of Dihang Dibang Biosphere Reserve of Arunachal Pradesh, India. Recorded butterflies belong to 81 genera and 8 families whereas in the present research 8 genera belonging to 3 families were reported. Nymphalidae comprises 28 genera, Papilionidae 9 and Pieridae 10 genera from the India. In contrast from the present survey it was found that Pieridae comprises 4 genera, Nymphalidae 3 and Paplionidae 1.

In the present research, administration area and main campus showed least butterfly fauna as compare to residential area because species composition and abundance is always dependent upon maintenance of natural habitat. Another reason is shortage of time, i.e., survey was carried out only for 4 months. If survey was done for long time there would have been a substantial increase in number of butterflies.

\section{CONCLUSION}

The present survey was conducted to evaluate the butterfly fauna of Hazara University, Mansehra, Pakistan during March-June 2012. Collection was done by twice and thrice visits to the study sites. Total number of specimens was 170 . The 8 genera comprised of 10 different species belonging to 3 families were recorded. These species were $P$. demoleus, $P$. polytes, $P$. daplidice, E. hecabe, P. ajaka, D. chrysippus, P. napi, C. carudi, J. orithya, and C. croceus.

\section{RECOMMENDATION}

Frequent survey should be done on large scale to fully 
evaluate the butterfly fauna of Hazara division, as it is least documented region of KP. Proper preventive measures should be taken in consideration in order to minimize the natural habitat loss, as butterfly fauna is dependent upon proper environmental conditions. Similar surveys on large scales are recommended to fully evaluate the butterfly fauna of Hazara division.

\section{ACKNOWLEDGEMENTS}

We are grateful to Dr. Ather Rafi, Director, National Insect Museum, NARC, Islamabad for identification of butterflies. The authors are grateful to Officials, Department of Zoology, Hazara University, Mansehra, Pakistan for providing laboratory facilities throughout the present research. The experiments comply with the current laws of the institution and country in which they were performed.

\section{REFERENCES}

[1] Maheshwari, J.K. (2003) Endangered pollinators. Environmental News Archives, 9, 32-45.

[2] Borror, D.J., Delong, D.M. and Triplehor, C.A. (1975) Order Lepidoptera. In: Anintroduction to the Study of Insects, New York, 462-534.

[3] Evans, W.H. (1932) Introduction. In: Identification of Indian Butterflies, 2nd Edition, Bombay Natural History Society, Mumbai, 1-35.

[4] Meyer, A. (2006) Repeating patterns of mimicry. Public Library of Science Biology, 4, 1675.

[5] Robbins, B. and Robert, K. (1981) The "false head" hypothesis: Predation and wing pattern variation of Lycaenid Butterflies. American Naturalist, 118, 770-775.

[6] Hall, J.P.W., Robbins, R.K. and Harvey, D.J. (2004) Extinction and biogeography in the Caribbean: New evidence from a fossil riodinid butterfly in Dominican amber. Proceedings of the Royal Society of London, 271, 797801. doi:10.1098/rspb.2004.2691

[7] Khan, M.R., Khan, M.R., Ali, K., Bashir, I., Malik, I.A. and Mir, A. (2004) Biodiversity of butterflies from districts Poonch and Sudhnoti, Azad Kashmir. Asian Journal of Plant Sciences, 3, 556-560. doi:10.3923/ajps.2004.556.560

[8] Bonebrake, T.C. and Sorto, R. (2009) Butterfly (Papilionoidea and Hesperioidea) rapid assessment of a Coastal Countryside in EI Salvador. Tropical Conservation Science, 2, 34-51.

[9] Sawchik, J., Dufrêne, M. and Lebrun, P. (2005) Distribution patterns and indicator species of butterfly assemblages of wet meadows in Southern Belgium. Belgian Journal of Zoology, 135, 43-52.

[10] Clark, P.J., Reed, M. and Chew, F.S. (2007) Effects of urbanization on butterfly species richness, guild structure, and rarity. Urban Ecosystem, 10, 321-337. doi:10.1007/s11252-007-0029-4

[11] Ilyas, M., Alam, M., Ahmad, H., Tariq, M., Bibi, S., Ali, A. and Inamullah (2009) Awareness regarding bioethical issues among the students and faculty of Hazara Univer- sity Mansehra, Pakistan. Pakistan Journal of Medical Sciences, 25, 97-102.

[12] Mustafa, G. (2003) Mansehra: An Introduction. ScienceReligion Dialogue Spring, 2003.

[13] Map of Mansehra (2012) http://www.nccrpakistan.org/research mapHazara.html

[14] Ali, I. (2005) Mapping and documentation of the cultural assets of Kaghan Valley, Mansehra. United Nations Educational, Scientific and Cultural Organization, Islamabad 5-6.

[15] Online (2012) http://hu.rozee.pk/view.php?lid=TVRVeCtF

[16] Sabir, A.M., Bhatti, A.H., Rafi, M.A. and Suhail, A. (2000) Distribution of Nymphalid butterflies (brush footed) in districts Rawalpindi and Islamabad. Pakistan Journal of Biological Sciences, 3, 1253-1254.

[17] Munir, M., Jasra1, A.W. and Rafique, S. (2008) Lamb production under different systems of management on rangelands of Balochistan. Pakistan Veterinary Journal, 28, 6870.

[18] Abbas, M., Rafi, M.A., Inayatullah, M., Khan, M.R. and Pavulaan, H. (2002) Taxonomy and distribution of butterflies (Papilionoidea) of the Skardu region, Pakistan. The Taxonomic Report of the International Lepidoptera Survey, 3, 1.

[19] Khan, M.R., Ahmad, R., Khan, M.R., Hayat, A. and Khalid, M. (2003) Diversity of butterflies from district Bagh, Azad Kashmir. Pakistan Journal of Biological Sciences, 6, 2007-2009. doi:10.3923/pjbs.2003.2007.2009

[20] Iqbal, J. (1978) A preliminary report on butterflies of district Rawalpindi and Islamabad. Biologia, 24.

[21] Ahson, M. and Iqbal, J. (1975) A contribution to the butterflies of Lahore with the addition of new records. Biologia, 21.

[22] Khan, M.R., Nasim, M., Khan, M.R. and Rafi, M.A. (2004) Diversity of butterflies from district Muzaffarabsd, Azad Kashmir. Pakistan Journal of Biological Sciences, 7, 324327. doi:10.3923/pjbs.2004.324.327

[23] Khan, M.R., Rafi, M.A., Munir, M., Hussain, S., Baig, M.W. and Khan, M.W. (2007) Biodiversity of butterflies from district Kotli, Mirpur and Bhimber, Azad Kashmir. Pakistan Journal of Zoology, 39, 27-34.

[24] Naz, F., Rafi, M.A., Inayatullah, M. and Tuzor, Y. (2001) The butterflies of the Buner district, North-West-Frontier Province, Pakistan. Helios Collection of Lepidopterological Articles, 2, 123-224.

[25] Shields, O. (1974) Towards the theory of butterfly migration. Journal of Research on the Lepidoptera, 13, 217238.

[26] Pandharipande, T. N. (1990) Butterflies from Nagpur City, Central India (Lepidoptera: Rhopalocera). Journal of Research on the Lepidoptera, 29, 157-160.

[27] Perveen, F. and Ahmad, A. (2012) Checklist of butterfly fauna of Kohat, Khyber Pakhtunkhwa, Pakistan. Arthropods, 1, 112-117.

[28] Perveen, F. and Ahmad, A (2012) Exploring butterfly fauna (Lepidoptera) of Kohat, Khyber Pakhtunkhwa, Pa- 
kistan. Signpost Open Access Journal of Entomological Studies, 1, 94-107.

[29] Sharma, G. and Joshi, P. C. (2009) Diversity of butterflies (Lepidoptera: Insecta) from Dholbaha dam (distt. Hoshiarpur) in Punjab Shivalik, India. Biological Forum: An International Journal, 1, 11-14.

[30] Ramesh, T., Hussain, K.J., Selvanayagam, M., Satpathy, K.K. and Prasad, M.V. R. (2010) Patterns of diversity, abundance and habitat associations of butterfly communities in heterogenous landscapes of the Department of Atomic Energy (DAE) Campus at Kalpakkam, South India. International Journal of Biodiversity and Conservation, 2, 75-85.

[31] Fermon, H., Schulze, C.H., Waltert, M. and Mühlenberg, M. (2001) The butterfly fauna of the Noyau Central, Lama Forest (Republic Of Benin), with notes on its ecological composition and geographic distribution. African Entomology, 9, 17-26.

[32] Tayyab, M., Suhail, A., Shazia and Arshad, M. (2006) Biodiversity of Lepidopterous insects in agro-forest area of Bahawalpur. Pakistan Entomologist, 28.

[33] Akhtar, M.S. and Butt, F.T. (2006) Study of seasonal variations of Danaus chrysippus (Linnaeus) from Lahore. Punjab University Journal of Zoology, 21, 9-17.

[34] Vu, L.V. and Vu, C.Q. (2011) Diversity pattern of butterfly communities (Lepidoptera, Papilionoidae) in different habitat types in a tropical rain forest of Southern Vietnam. International Scholarly Research Network (ISRN) Zoology, 1-8.

[35] Khan, M.R., Rafi, M.A., Ilyas, M. and Safder, M. (2000) Distribution and diversity of Papilio spp. (Papilionidae: Lepidoptera) Rawalpindi and Islamabad. Pakistan Journal of Scientific Research, 52, 1-3.

[36] Rafi, M.A., Matin, M.A., Sheikh, M.K. and Ashfaque, M. (2004) Papilionid fauna of districts Rawalpindi and Islamabad with new records of three species Viz. Papilio machaon L., Chilisa clytia (L.) and Graphium sarpedon (L.). Journal of Natural History Wildlife, 3, 13-16.
[37] Homziak, N.T. and Homziak, J. (2006) Papilio demoleus (Lepidoptera: Papilionidae): A New record for the United States, commonwealth of Puerto Rico. Florida Entomologist, 89, 485-488. doi:10.1653/0015-4040(2006)89[485:PDLPAN]2.0.CO;2

[38] Klimczuk, P. (2011) Butterflies (Lepidoptera: Hesperioidea, Papilionoidea) of the Knyszyn Forest (Puszcza Knyszynska) and adjacent woodland areas of Bialystok. In the Years 1995-2010. Opole Scientific Society Nature Journal, 44, 197-217.

[39] Shah, M., Rafi, M.A. and Inayatullah, M. (2001) Some pierids butterflies of Kohat district. Sarhad Journal of Agriculture, 17, 407-413.

[40] Martinez, A.L., Bousquets, J.L., Fernandez, I.V. and Warren, A.D. (2003) Biodiversity and biogeography of Mexican butterflies (Lepidoptera: Papilionoidea and Hesperioidea). Proceedings of the Entomological Society of Washington, 105, 209-224.

[41] Perveen, F., Ahmad, A. and Yasmin, N. (2012) Characterization of butterflies (Lepidoptera) of Kohat, Khyber Pakhtunkhwa, Pakistan. Pakistan Journal of Entomology, Karachi, 27, 15-26.

[42] Perveen, F. (2012) Distribution of butterflies (Lepidoptera) of Kohat, Khyber Pakhtunkhwa, Pakistan. Agricultural Science Research Journal, 2, 539- 549.

[43] Ambrose, D.P. and Raj, D.S. (2005) Butterflies of KalakadMundanthurai Tiger Reserve, Tamil Nadu. Zoos' Print Journal, 20, 2100-2107. doi:10.11609/JoTT.ZPJ.1312.2100-7

[44] Hiller, L.R.M. (2007) A method to identify the three cryptic species of Protesilaus, (Lepidoptera: Papilionidae) from Southern Brazil, based on genital morphology. Review of Biology of Tropics, 55, 665-671.

[45] Borang, A., Bhatt, B.B., Tamuk, M., Borkotoki, A. and Kalita. J. (2008) Butterflies of Dihang Dibang biosphere reserve of Arunachal Pradesh, Eastern Himalayas, India. Bulletin of Arunachal Forest Research, 24, 41-53. 